Article

\title{
The Influence of an Integrated Driving on the Performance of Different Passive Heating and Cooling Methods for Buildings
}

\author{
Ivan Oropeza-Perez \\ Department of Architecture, Universidad de las Americas Puebla, Ex Hacienda Sta. Catarina Martir, \\ San Andres Cholula 72810, Puebla, Mexico; ivan.oropeza@udlap.mx
}

Received: 18 September 2019; Accepted: 20 October 2019; Published: 23 October 2019

check for updates

\begin{abstract}
Passive cooling and heating methods within buildings are studied a lot nowadays. Nevertheless, their performance considering their driving has not been deeply studied. Therefore, the performance of the most common passive heating and cooling methods is analyzed in this document. The methods are divided into three categories: operable, semi-operable, and not operable. They are studied under different conditions of operation in order to estimate their performance in terms of indoor temperature increase/decrease in a single dwelling. The study is carried out with the thermal simulation program EnergyPlus, using a dwelling in Mexico City as a case study, which is validated with literature that studied passive methods for similar climates. Furthermore, for an integrated driving, four features of operation of the passive methods are considered: mobility, maintenance, assembly, and consumables. The results show that a correct use of these features of driving might achieve a significant temperature drop in the case of cooling and a significant indoor temperature increase in the case of heating. This is reflected in a considerable amount of energy saving compared to a conventional heating/cooling heat-pump system running under regular conditions, which is taken as a reference of consumption. Thereby, it is concluded that the proper usage, considered here as the correct application of the four features of operation mainly by the occupants, might have a high influence in their performance of increase/decrease of the indoor temperature. Thus, it is highly recommended to follow up their performance once installed and not to suppose an optimal performance ever after.
\end{abstract}

Keywords: passive cooling; passive heating; integrated driving; effectiveness of operation; features of operation

\section{Introduction}

The current situation in the world obligates new and innovative manners of providing the everyday growing energy necessary to keep the levels of production and way-of-life of humans. Moreover, it is well-known that global warming, closely related to energy activities, is a threat that has to be addressed immediately by the current and the future generations [1,2].

One of the manners of countering climate change is related to the efficient use of energy. In this context, the building sector is a key target due to its share of the world's energy use (40\%) [3]. Out of this consumption, one of the most consuming activities within the buildings is the space conditioning, either for cooling or for heating [4].

In this sense, passive cooling and heating strategies were developed to achieve thermal comfort without spending great amounts of energy and other resources. In all cases, the methods decrease or increase the indoor temperature, depending on their original purpose [5-14]. Nevertheless, sometimes these methods are not capable of reaching the same temperature drop, in the case of 
cooling, and temperature increase, in the case of heating, as active methods such as heat pumps, air-conditioning (AC), or radiation systems [15].

Concerning the passive methods, a review shows that they can be divided according to their positive or negative heat-flow path onto the building heat balance, when this one does not have any active heating or cooling system (free-running building). These paths can be generally classified as the following: internal heat gains, heat transfer through the envelope, and heat transfer between the indoor and the outdoor air (see Figure 1).

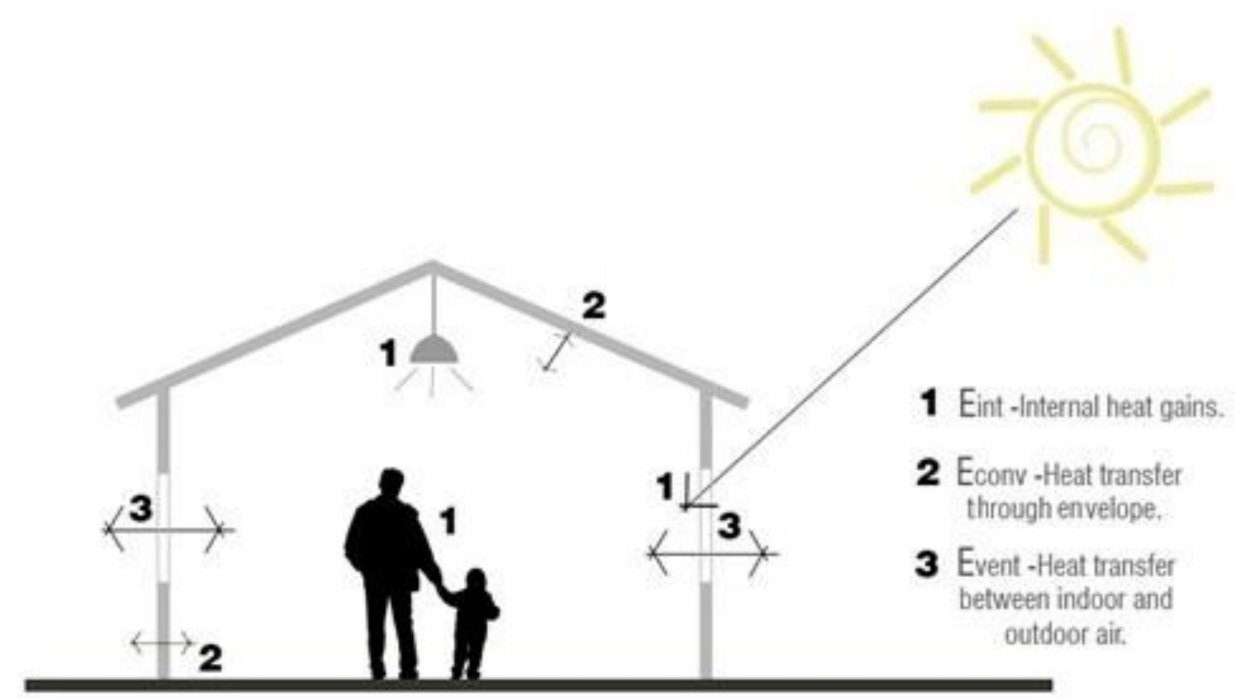

Figure 1. Different heat-flow paths within a free-running building, derived from authors' elaboration.

In general, the heat transfer is by radiation for the internal heat gains, conduction for the heat transfer through the envelope, and convection for the heat transfer between the indoor and outdoor air. Nevertheless, the heat transfer manner might vary for some passive methods. Thereby, the most studied and used passive methods can be gathered as follows (Table 1).

Table 1. Classification of passive methods by heat flow.

\begin{tabular}{cc}
\hline Heat Flow & Passive Method [16-52] \\
\hline Internal heat gains & $\begin{array}{c}\text { Passive solar gain } \\
\text { Shading systems }\end{array}$ \\
\hline & Thermal insulation \\
& Double-glazed opening \\
Phase change materials & Passive cooling shelter \\
& Heat sink \\
& Thermal capacity \\
Heat transfer through the envelope & Radiant heat barrier \\
outdoor air & Infiltration control \\
& Eco-evaporative cooling \\
& Natural ventilation \\
& Solar-assisted AC \\
\hline Multiple heat transfer means & Intelligent facade \\
\hline
\end{tabular}

Table 1 presents the most studied and used passive cooling and heating methods. Out of the fourteen presented methods, and according to the literature review, passive solar gain and infiltration control aim to heat up the space. Intelligent facade, thermal insulation, and double-glazed opening have both heating and cooling as their objectives, while the remaining nine methods are generally used for 
cooling [53,54]. Furthermore, from the literature review, it is seen that, out of the 37 reviewed documents, 35 present studies under similar climate conditions, i.e., group C and D of the Köppen-Geiger climate classification system [3]. Hence, a comparison between the reviewed methods and their use in a similar climate could be carried out in this document.

Furthermore, one of the most influencing factors for the proper performance of passive methods is operation, understood as the handling that the passive methods need in order to increase or decrease the indoor temperature, according to the case. For instance, to keep the indoor heat gain is necessary to close all the openings; to block the sunbeams the blinds must be shut; or to reflect the solar radiation the building should be white-painted. These handlings could be in a short, medium, or long period of time, depending on the method and its features.

Nevertheless, to the best of our knowledge, no study deals with the operation features and their influence on the passive methods' performance. In this sense, the occupants are only seen as a response of the energy consumption performance (not only by passive and active methods but also by others such as appliances and illumination), depending on their necessities and comfort levels [55-63]. The passive methods are generally considered static, where, once installed, there is not a driving beyond a certain amount of maintenance and when they break down, if it is the case. Although some passive methods are dynamic and can be controlled automatically or manually by the occupants [64-70], there are other features to take into account if the passive methods are considered with an integrated driving.

Thus, in this document, the aforementioned passive heating and cooling methods are analyzed in terms of their operation characteristics. A case study in Mexico City is presented in the document, considering that this city is suitable to compare to places with similar climates when assessing the reviewed passive methods, as was mentioned before.

The purpose of this is to determine the extent of drop/increase of the indoor temperature according to the corresponding handling of each passive method and to develop a guidance of operation in order to optimize their performance. Nonetheless, the geographical scope of this study is limited to locations with warm-to-hot conditions that present warm summers and cold winters (groups C and D of the Köppen-Geiger climate classification system).

\subsection{Classification by Time between Driving}

The different passive methods can be gathered according to one type of performance, namely, the period of time between one driving and another. In this case, a driving is understood as any kind of maintenance, operation, fixing, or other action that the building user applies to the passive method in order to correct or modify its performance. The classification of the passive methods is carried out by taking into account the amount of time between each driving, as shown in Table 2 .

Table 2. Classification of passive methods by time between driving.

\begin{tabular}{cc}
\hline Classification & Time Between Driving \\
\hline Operable & $\leq 1$ week \\
Semi-operable & $>1$ week $\leq 1$ year \\
Not operable & $>1$ year \\
\hline
\end{tabular}

Considering the fourteen passive methods available (two for heating, nine for cooling, and three for both heating and cooling) as the most used nowadays within dwellings [62,63], a classification of these methods by their time between driving can be carried out. Table 3 shows this classification, along with the main purpose of each method, i.e., heating, cooling, or both. For further information about the characteristics and the time between driving of the passive methods, please refer to $[62,63]$. 
Table 3. Classification of the passive cooling and heating methods by time between driving.

\begin{tabular}{cc}
\hline Passive Method & Operation Condition \\
\hline Heating & Operable \\
Passive solar gain & Semi-operable \\
Infiltration control & \\
Cooling & Operable \\
Shading system & Not operable \\
Phase change material & Semi-operable \\
Passive cooling shelter & Semi-operable \\
Heat sink & Not operable \\
Thermal capacity & Semi-operable \\
Radiant heat barrier & Operable \\
Eco-evaporative cooling & Operable \\
Natural ventilation & Operable \\
Solar-assisted AC & \\
Heating/Cooling & Not operable \\
Thermal insulation & Semi-operable \\
Intelligent facade & Operable \\
Double-glazed opening &
\end{tabular}

From Table 3, it can be seen that only three methods are considered to be not operable, while the other eleven need some kind of driving before one year passes after installation.

\subsection{Features of Operation}

The operation of the passive methods is also classified by their features. These characteristics are stated in this document as the following:

- Mobility. Related to the self-adjustment of the passive method for maximizing its performance according to the external and internal conditions; it is also defined as the control of the method, e.g., the opening of two opposite doors for cross ventilation.

- Maintenance. Understood as all physical action applied to the passive-method mechanism in the long-term for increasing its performance. For instance, to clear the window glass for passive solar heating.

- Assembly. Stated with regard to its placement and displacement according to the status of the passive method. For example, the placement of an external window shutter to keep the indoor heat.

- Consumables. Defined as the resources used to perform the passive methods. One example of this is the water used to decrease the indoor temperature by applying eco-evaporative cooling.

Thereby, Table 4 can be constructed. In this table, the heating and cooling passive methods are shown, along with their main operation features. As it can be seen in Table 4, apart from the three not-operable methods, which only need a certain level of maintenance, all passive methods have at least two features of operation that imply the driving by the occupants. The variation of these features makes an integrated driving, which is related to their performance, which is hereby called the effectiveness of operation of the methods. 
Table 4. Classification of passive cooling and heating methods by operation features.

\begin{tabular}{cc}
\hline Passive Method & Operation Features \\
Heating & Mobility, maintenance \\
Passive solar gain & Mobility, maintenance, assembly \\
Infiltration control & \\
Cooling & Mobility, maintenance, assembly \\
Shading system & Maintenance \\
Phase change material & Mobility, maintenance, consumables \\
Passive cooling shelter & Maintenance, consumables, assembly \\
Heat sink & Maintenance \\
Thermal capacity & Maintenance, consumables, assembly \\
Radiant heat barrier & Mobility, maintenance, assembly, consumables \\
Eco-evaporative cooling & Mobility, assembly \\
Natural ventilation & Mobility, maintenance, consumables \\
Solar-assisted AC & Maintenance \\
Heating/Cooling & Mobility, maintenance, consumables \\
Thermal insulation & Mobility, maintenance \\
Intelligent facade &
\end{tabular}

\section{Methodology}

\subsection{Effectiveness of Operation}

The effectiveness of operation of the methods could be estimated. This effectiveness is stated as the difference between the indoor air temperature increase/decrease that can be achieved and a previously set indoor temperature of comfort, as shown in Equation (1), developed for this document to obtain a linear comparison between the values:

$$
\varphi=100-\left(\frac{\left|T_{\text {Comfort }}-T_{\text {Passive }}\right|}{T_{l-u}} \cdot 100\right)
$$

The effectiveness has a value between $0 \%$ and $100 \%$, where the range of thermal comfort is delimited by a lower and an upper threshold, $T_{l-u}$, which is in accordance with international standards, such as ASHRAE 55 and EN 15251 [71]. Nonetheless, it is worth mentioning that the thermal comfort range can vary due to other factors, such as clothing, metabolic rate, or relative humidity, among others, and depends on human factors, such as the psychological and physiological perception [71].

Thereby, for instance, Figure 2 shows the effectiveness of a passive method with a temperature setpoint of $22{ }^{\circ} \mathrm{C}$, considering a thermal comfort range between 18 and $26{ }^{\circ} \mathrm{C}\left(T_{l-u}=4{ }^{\circ} \mathrm{C}\right)$. In this case, if a passive method achieves $22{ }^{\circ} \mathrm{C}$, its effectiveness is $100 \%$. If it achieves $23{ }^{\circ} \mathrm{C}$, its effectiveness would be $75 \%$.

It is worth to mentioning that the effectiveness calculated by Equation (1) is a subjective value that depends on two features: the temperature of comfort and the lower and upper threshold. Both values are taken from adaptive thermal comfort models that are dependent on both physical and human factors [71]. Therefore, the effectiveness of operation is a fixed value to indicate how well a method heats up or cools down a space, but it is not free of accuracy fails and perception errors. 


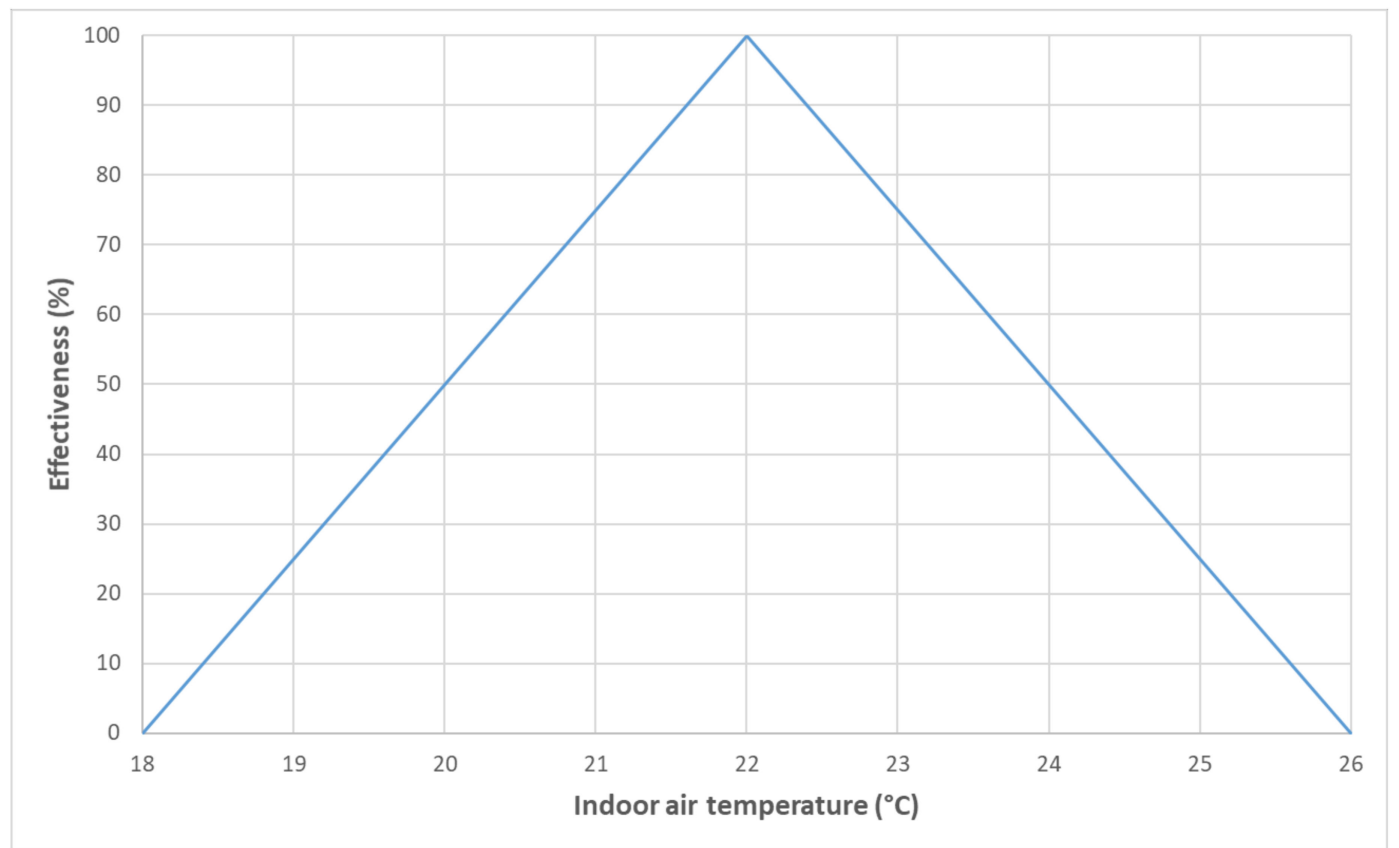

Figure 2. Effectiveness of the passive method for a temperature of comfort of $22{ }^{\circ} \mathrm{C}$.

\subsection{Influence of Performance}

Another concept that is introduced in this document is the 'influence of performance', which is defined as the influence that the four aforementioned operation features have upon the performance (temperature increase/decrease) of the passive methods. For defining a value of this influence of performance, it is considered that the operation features have an index of influence, shown in Table 5 . It is considered that the four indexes have $100 \%$ influence over the decrease or increase of the indoor temperature. Furthermore, the values were weighted according to the literature review of the passive methods, where these four operation features are presented with different performances, if they are applied. The index of influence of each operation feature was estimated based on the temperature increase or decrease presented in the reviewed documents.

Table 5. Value of the influence index of the operation features.

\begin{tabular}{cc}
\hline Operation Feature & Influence Index (\%) \\
\hline Mobility & 35 \\
Maintenance & 15 \\
Assembly & 30 \\
Consumables & 20 \\
\hline
\end{tabular}

Thereby, depending on the number of operation features, the passive method can decrease or increase the indoor temperature at a maximum value (influence of performance of $100 \%$ ). If the passive method does not have any operation feature, it is considered that the influence of performance is $0 \%$, i.e., there is no variation in the indoor temperature. Figure 3 can be displayed showing the influence of performance of the fourteen passive heating and cooling methods.

In Figure 3, it can be noticed that the only method that can be $100 \%$ controlled is eco-evaporative cooling, whereas phase change material and thermal capacity have only up to $15 \%$ of the indoor temperature variation when their only operation feature (maintenance) is applied. 


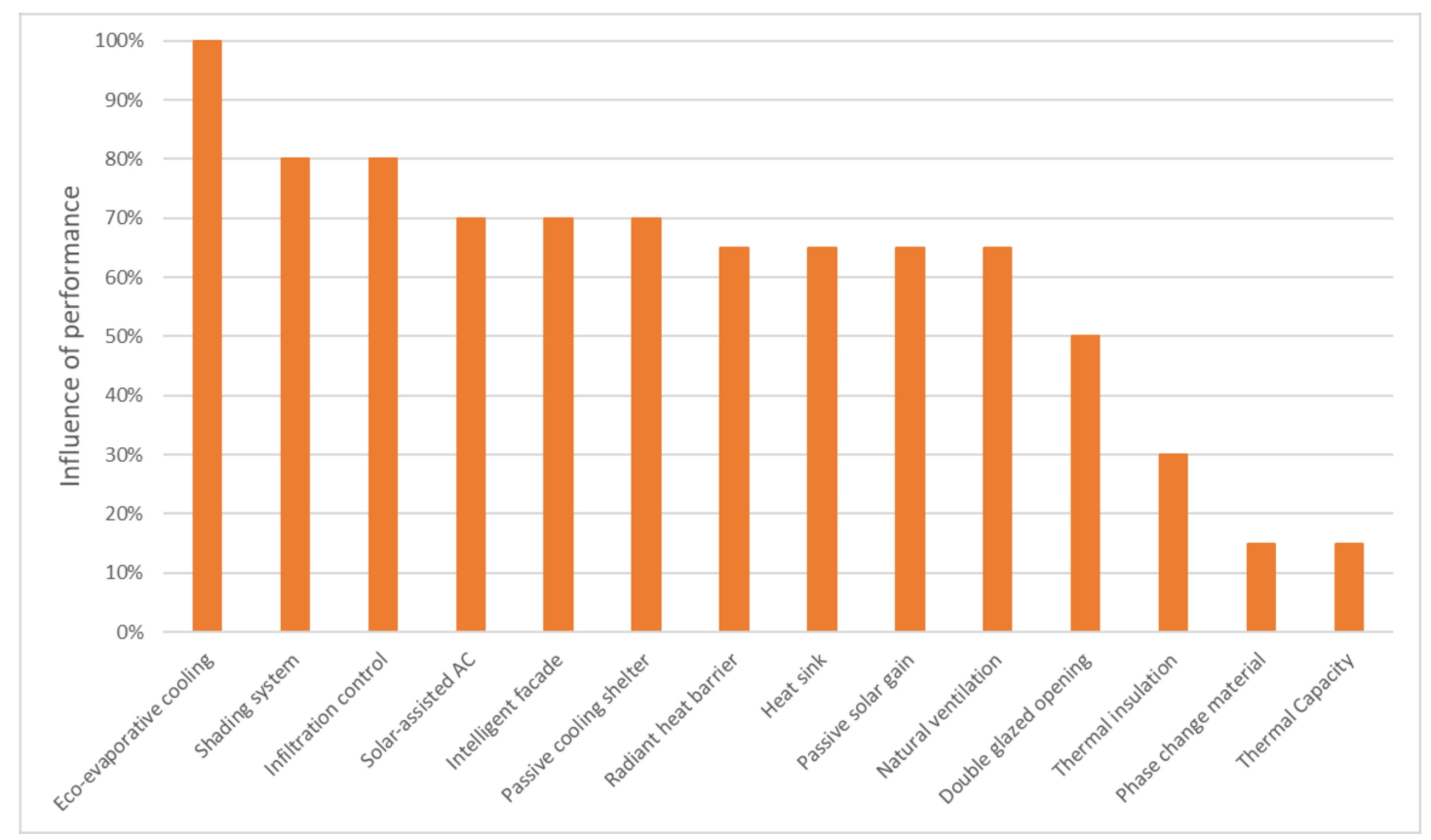

Figure 3. Influence of performance of the passive methods.

\section{Results}

\subsection{Passive Methods' Performance}

The performance and therefore the effectiveness of the passive methods is determined by the indoor temperature that each method achieves in particular. For this, the thermal simulation program EnergyPlus [72] is used in order to calculate the indoor temperature by utilizing the different passive methods. When the indoor temperature is calculated, it is compared to the temperature of comfort by using Equation (1) and thus estimating the effectiveness $\varphi$.

\subsection{Characteristics of the Simulation Modelling}

The estimation of the indoor temperature is carried out in an hourly way for the warmest and the coldest day of the year, respectively, taking a dwelling in Mexico City as a case study. This city was chosen because it represents, in a clear manner, a warm cooling season (average maximum outdoor temperature of $30.15^{\circ} \mathrm{C}$ ) and a cold heating season (average minimum outdoor temperature of $\left.2.75^{\circ} \mathrm{C}\right)[73,74]$, considered as $\mathrm{Cwb}$ in the Köppen-Geiger climate classification system. The temperature of comfort was set at $22^{\circ} \mathrm{C}$, as is established for Mexico, with a thermal comfort range between 18 and $26^{\circ} \mathrm{C}[71]$.

One single dwelling is studied in the document. The modelled dwelling has the most common materials in Mexico (brick walls of $10 \mathrm{~cm}$ of width and a concrete roof of $30 \mathrm{~cm}$ of width, with four windows of $6 \mathrm{~mm}$ clear glass), with an average built area of $120 \mathrm{~m}^{2}$ and a ceiling height of $2.2 \mathrm{~m}$ (see Figure 4). Furthermore, the occupancy was stated as a regular home schedule (absences during the day and full occupation during the night), considering four occupants with mechanical heat gains of $1000 \mathrm{~W}$. For the simulation model, it is considered that the dwelling has a backyard and it is placed within a low, dense urban area (see Figure 5), where its external walls are adiabatic with the adjacent surfaces. It is also considered that the south facade is fully sun-exposed. 


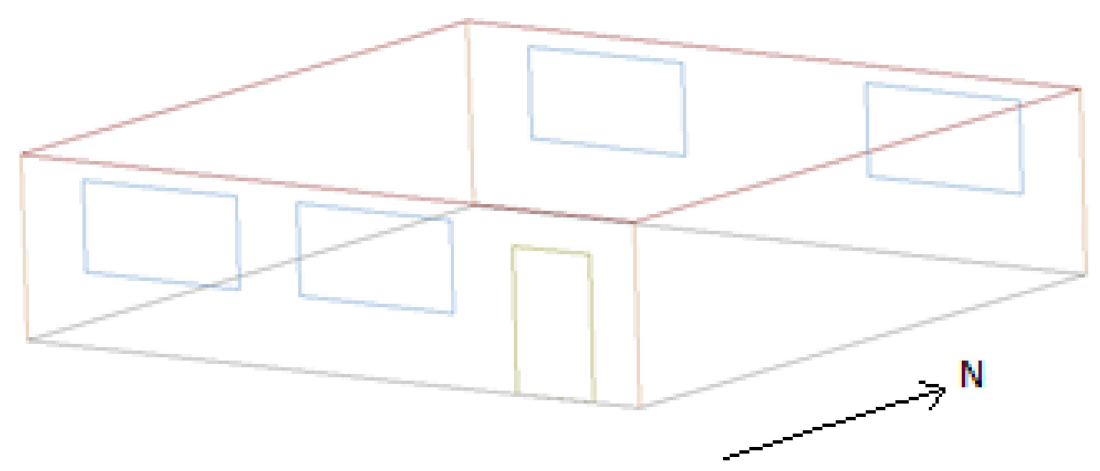

Figure 4. Geometry of the simulated dwelling. Source: own elaboration based on EnergyPlus.

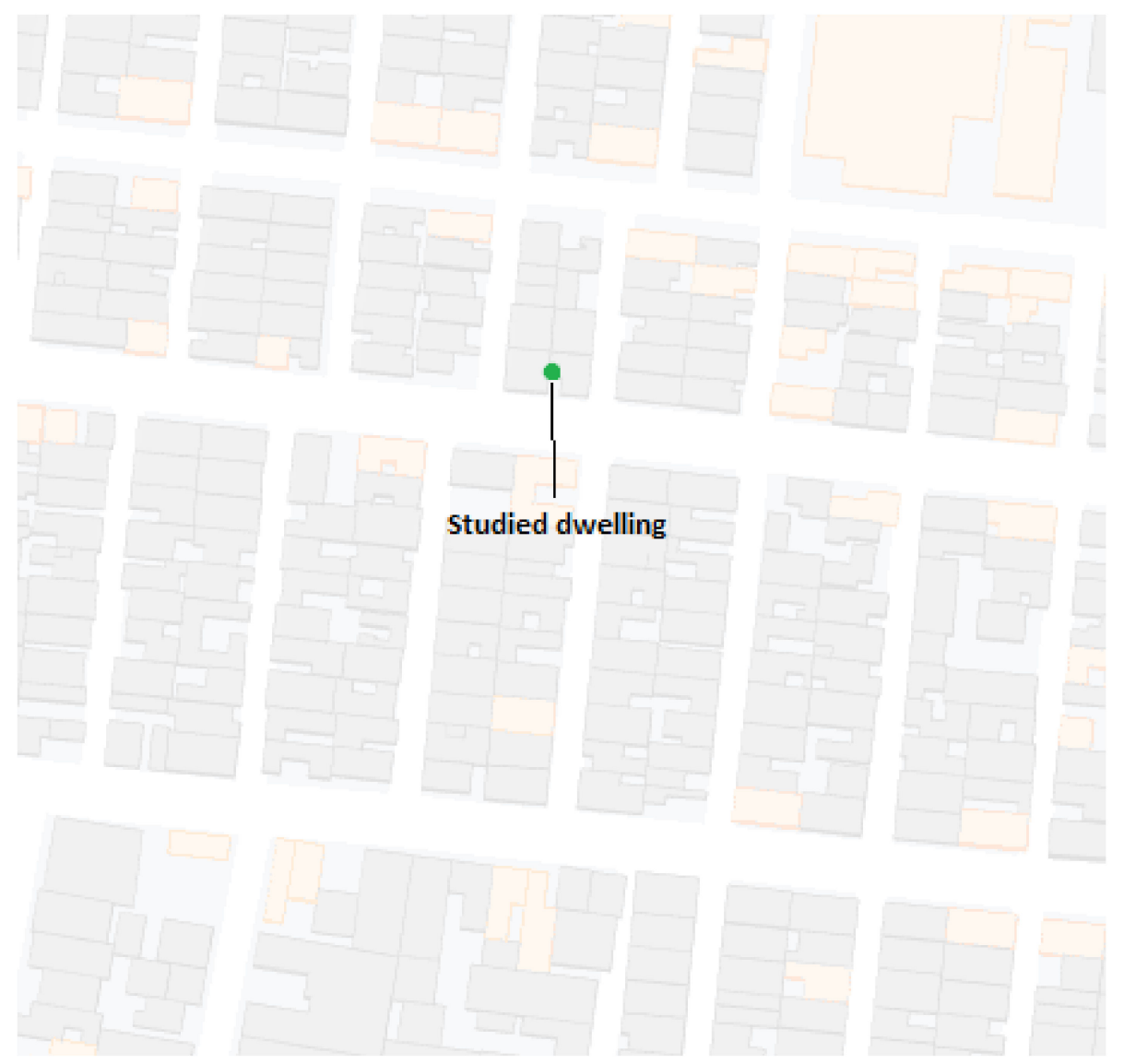

Figure 5. Urban location of the simulated dwelling (green dot) [75].

Furthermore, to estimate the hourly indoor temperatures achieved by the respective passive methods within the simulation modelling, different assumptions were considered. For instance, the indoor temperature achieved by radiant heat barriers was calculated by increasing the reflectivity of the surface; the performance of thermal insulation was estimated by including an extra layer of insulation material; or for thermal capacity, the heat capacity of the walls' material was enhanced.

\subsection{Results of Simulation}

Within the EnergyPlus program, the characteristics of the modelling (schedule, materials of construction, geometry, location, etc.) are set as input data. The characteristics of the passive methods are also set as inputs, mainly by changing the physical characteristics of the building (double-glazed windows, radiant heat barriers, controlled natural ventilation, etc.). Using the simulation modelling 
for every passive method, Table 6 is constructed, considering that the temperatures were achieved without any kind of control, mobility, or maintenance by the occupants and setting a temperature of comfort of $22^{\circ} \mathrm{C}$.

Table 6. Indoor temperature of passive cooling and heating methods without any occupants driving.

\begin{tabular}{ccc}
\hline Passive Method & Highest Temperature ${ }^{\circ} \mathbf{C}$ (Heating) & Lowest Temperature ${ }^{\circ} \mathbf{C}$ (Cooling) \\
\hline Heating & & - \\
Passive solar gain & 10.84 & - \\
Infiltration control & 11.89 & 24.86 \\
Cooling & & 22.96 \\
Shading system & - & 31.61 \\
Phase change material & - & 23.97 \\
Passive cooling shelter & - & 24.65 \\
Heat sink & - & 26.31 \\
Thermal capacity & - & 31.27 \\
Radiant heat barrier & - & 24.71 \\
Eco-evaporative & - & 32.44 \\
cooling & - & \\
Natural ventilation & - & 28.83 \\
Solar-assisted AC & 15.17 & 24.80 \\
Heating/Cooling & 19.20 & 25.73 \\
Thermal insulation & 11.78 & \\
Intelligent facade & & \\
Double-glazed opening & & \\
\hline
\end{tabular}

In Table 6, it can be seen that none of the methods reach the comfort indoor temperature $\left(22^{\circ} \mathrm{C}\right)$. Therefore, the operation features must be applied in order to achieve thermal comfort with the passive methods.

\subsection{Validation of the Results}

The results obtained by the simulations are compared with previous works that focused on the thermal performance of certain methods [62,76-78]. It is worth mentioning that some passive methods have not been thermally analyzed; thus, there is no data available. Also, it is important to clarify that, in most of the cases, the conditions of construction, occupancy, and others were not exactly the same, and thus it is expected to have certain discrepancies with the simulated results.

Thereby, the comparison of the indoor temperatures can be seen in Table 7. In the table, the highest simulated indoor temperature increase or decrease is taken into account and it is compared to the highest indoor temperature increase or decrease taken from the literature review.

As seen in Table 7, the highest error between the reviewed indoor temperature increase/decrease and the simulated one is the given by passive solar gain (36\%). In all cases, the error can be considered as acceptable. Furthermore, since References [62,76-78] are carried out under climate conditions within groups $C$ and $D$ of the Köppen-Geiger classification, and, along with the reviewed passive methods of References [16-52], it is considered that the methods are working under similar conditions; hence, the results can be stated as valid. 
Table 7. Comparison of the thermal performance of the passive methods.

\begin{tabular}{cccc}
\hline Passive Method & $\begin{array}{c}\text { Averaged Reviewed } \\
\text { Temperature Increase/Decrease } \\
\left({ }^{\circ} \mathbf{C}\right) \text { [16-52,62,76-78] }\end{array}$ & $\begin{array}{c}\text { Simulated Temperature } \\
\text { Increase/Decrease }\left({ }^{\circ} \mathbf{C}\right)\end{array}$ & Error (\%) \\
Heating & 7 & 11 & 36 \\
Passive solar gain & NA & 10 & NA \\
Infiltration control & 3 & 3 & 0 \\
Cooling & NA & 6 & NA \\
Shading system & 20 & 15 & 25 \\
Phase change material & 6 & 7 & 14 \\
Passive cooling shelter & 8 & 7 & 31 \\
Heat sink & 13 & 9 & 25 \\
Thermal capacity & 6 & 8 & 7 \\
Radiant heat barrier & 15 & 14 & 25 \\
Eco-evaporative cooling & 20 & 15 & 22 \\
Natural ventilation & & & 20 \\
Solar-assisted AC & 9 & 7 & 25 \\
Heating/Cooling & 10 & 8 & 15 \\
Thermal insulation & 22 & & \\
Intelligent facade & & & \\
Double-glazed opening & & & \\
\hline
\end{tabular}

\subsection{Effectiveness of the Passive Methods}

By applying Equation (1) and the results shown in Table 6, Figure 6 can be displayed with the effectiveness of each passive method. It is important to mention that, because in the literature it is generally expressed in this manner, for thermal insulation and double-glazed opening, it is considered the temperature of heating, whereas, for intelligent facades, the temperature of cooling was taken into account.

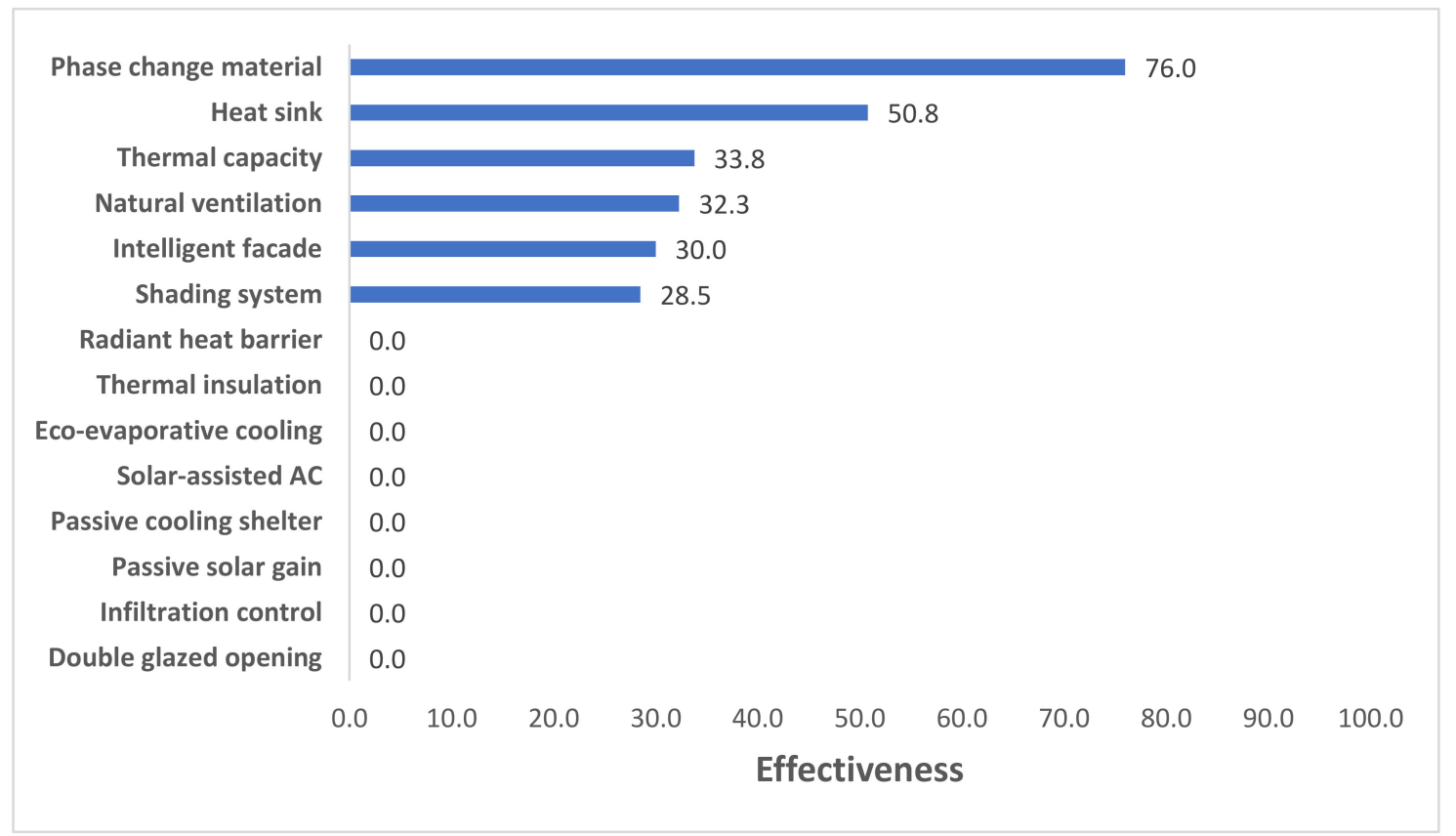

Figure 6. Effectiveness of the passive methods for a comfort temperature of $22{ }^{\circ} \mathrm{C}$.

From Figure 6, one can see that eight out of the fourteen passive methods do not accomplish a minimal effectiveness to be considered a correct method for achieving thermal comfort. It can also be seen that, out of the six methods that fulfill the minimal effectiveness, two of them, i.e., phase change 
material and thermal capacity, are defined as not operable. These results are good because only one operation feature can be applied upon them (see Table 4); therefore, once they are installed, they do not need driving often.

Regarding the other passive methods, and placing emphasis onto the eight that did not accomplish the effectiveness, the operation features mentioned in Table 4 and Figure 3 are varied until their optimal effectiveness is reached. The operation features are changed in the simulation modelling onto the physical characteristics of the building design and the variation of the occupant schedule. Therefore, results of the indoor temperature with a proper occupants driving can be shown in Table 8 . In real life, this change of characteristics to the simulation modeling is seen, for example, as the following:

- Mobility. Opening of the windows and doors to enhance natural ventilation. Opening and closing of blinds to either allow or block the direct solar gains. Adapting a double-glazed window to retain or expel heat. Etc.

- Maintenance. Cleaning of the windows. Watering of green surfaces. Cleaning of reflective surfaces. Draining of the pipelines of the passive cooling shelter. Etc.

- Assembly. Placement of sealing material into cracks of windows and doors to increase airtightness. Placement of more transparent blinds to allow direct solar gains. Etc.

- Consumables. Use of water in a swimming pool to create a natural heat sink. Water for eco-evaporative cooling. Working fluid of a solar-assisted AC. Etc.

Table 8. Indoor temperature of passive cooling and heating methods with occupants driving.

\begin{tabular}{ccc}
\hline Passive Method & Highest Temperature ${ }^{\circ} \mathbf{C}$ (Heating) & Lowest Temperature ${ }^{\circ} \mathbf{C}$ (Cooling) \\
\hline Heating & 18.72 & - \\
Passive solar gain & 18.58 & - \\
Infiltration control & & 24.60 \\
Cooling & - & 22.56 \\
Shading system & - & 24.05 \\
Phase change material & - & 23.04 \\
Passive cooling shelter & - & 23.61 \\
Heat sink & - & 22.74 \\
Thermal capacity & - & 22.66 \\
Radiant heat barrier & - & 22.32 \\
Eco-evaporative & - & 23.44 \\
cooling & - & 25.84 \\
Natural ventilation & 18.16 & 24.11 \\
Solar-assisted AC & 19.89 & 23.34 \\
Heating/Cooling & 18.54 & \\
Thermal insulation & & \\
Intelligent facade & & \\
Double-glazed opening & & \\
\hline
\end{tabular}

As mentioned previously, the physical characteristics of the simulation modelling were varied (increasing the thermal transmittance for passive heating, decreasing the thermal absorption for radiant heat barrier, etc.). Thereby, from the indoor temperature values of Table 8 achieved by each passive method, Figure 7 is constructed. One more time, for thermal insulation and double-glazed opening, the achieved temperature of heating was considered, whereas, for intelligent facades, the temperature of cooling was taken into account.

Figure 7 shows that the effectiveness of almost all the passive methods had a considerable improvement by handling one or more operation features (mobility, maintenance, assembly, and consumables). 


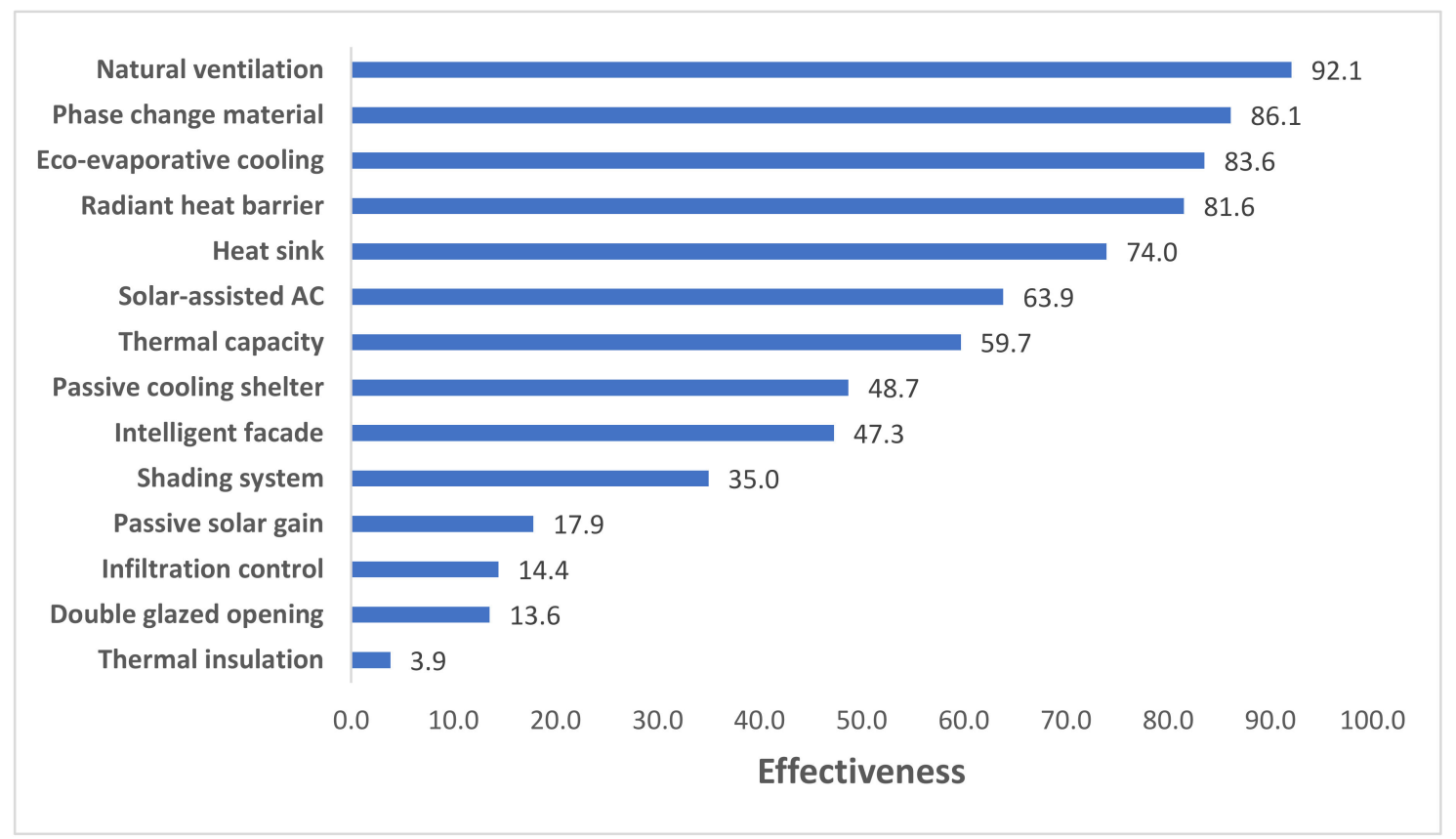

Figure 7. Effectiveness of the passive methods for a comfort temperature of $22{ }^{\circ} \mathrm{C}$ and having a driving by the occupants.

Analyzing the results, it can be seen that the highest improvements of the effectiveness were achieved by the passive methods that have high percentages of the influence of performance (cf. Figure 3), i.e., eco-evaporative cooling, solar-assisted AC, radiant heat barriers, passive cooling shelter, and natural ventilation. These passive methods have the advantage of giving users control over them (mobility), along with other operation features, such as often requiring maintenance and allowing for the use of consumables (electricity, water, refrigerant, etc.). Furthermore, the classification by operation conditions (cf. Table 3 ) indicates that they are considered to be operable or semi-operable methods.

Moreover, the three passive methods considered as not operable reached low improvements. This is explained for the low values of influence of performance (cf. Figure 3) that these methods present and which are reflected in a certain maintenance over a period of more than one year.

\subsection{Energy Saving Estimation}

Taking as the baseline a heat pump with an average coefficient of performance (COP) of 2.1 for both heating and cooling [79], the energy consumption for each heating/cooling method to achieve thermal comfort can be calculated. For this, it is considered that the heat pump works for both heating and cooling during the necessary hours of the year (heating when the hourly temperature is below the temperature of comfort and cooling when it is above). Thereby, the energy consumption based upon the hourly difference between the indoor temperature and the temperature of comfort is used, as shown in Equation (2) [80]:

$$
E C=\frac{\text { mass } \cdot C_{p} \cdot\left|T_{\text {Comfort }}-T_{\text {Passive }}\right|}{3600 \cdot C O P}
$$

In this case, a period of $1 \mathrm{~h}(3600 \mathrm{~s})$ is used, having hourly values of the energy consumption that are aggregated during an annual period ( 8760 hours). Thereby, it is considered a regular dwelling of $120 \mathrm{~m}^{2}$ of built area and $2.2 \mathrm{~m}$ of height [81], and a temperature of comfort of $22^{\circ} \mathrm{C}$. The specific heat of the air is set at $1.012 \mathrm{~kJ} / \mathrm{kg}^{\circ} \mathrm{C}$, and the air density is at $1.2 \mathrm{~kg} / \mathrm{m}^{3}$ [82]. With this, and using the heat 
pump calculator by Oropeza-Perez [83], Table 9 can be constructed, whereby the energy consumption with the temperatures achieved by the passive methods without any handling is displayed.

Table 9. Annual energy consumption by using different passive methods.

\begin{tabular}{cc}
\hline Passive Method & Annual Consumption (kWh) \\
\hline No passive method & 1990 \\
Heating & \\
Passive solar gain & 1340 \\
Infiltration control & 1380 \\
Cooling & \\
Shading system & 1350 \\
Phase change material & 1650 \\
Passive cooling shelter & 1640 \\
Heat sink & 1540 \\
Thermal capacity & 1110 \\
Radiant heat barrier & 360 \\
Eco-evaporative cooling & 1340 \\
Natural ventilation & 1370 \\
Solar-assisted AC & 1410 \\
Heating/Cooling & 1230 \\
Thermal insulation & 1430 \\
Intelligent facade & 1430 \\
Double-glazed opening &
\end{tabular}

In Table 9, it is clearly seen that the methods without any driving have almost the same amount of energy consumption as is found in a conventional dwelling without any passive method. Therefore, if the improved effectiveness of the methods is taken into account to reach the temperature of comfort, Table 10 can be displayed with the new annual energy consumption.

Table 10. Annual energy consumption by using different passive methods and using operation features by the users.

\begin{tabular}{cc}
\hline Passive Method & Annual Consumption (kWh) \\
\hline No passive method & 1990 \\
Heating & \\
Passive solar gain & 92 \\
Infiltration control & 101 \\
Cooling & \\
Shading system & 182 \\
Phase change material & 87 \\
Passive cooling shelter & 59 \\
Heat sink & 105 \\
Thermal capacity & 103 \\
Radiant heat barrier & 13 \\
Eco-evaporative cooling & 18 \\
Natural ventilation & 65 \\
Solar-assisted AC & 36 \\
Heating/Cooling & \\
Thermal insulation & 110 \\
Intelligent facade & 41 \\
Double-glazed opening & 105 \\
\hline
\end{tabular}

Table 10 shows that there is a considerable reduction of the energy consumption with all methods by having a correct driving of them. The highest consumption (shading systems) is 10 times smaller than the consumption without any passive method, which confirms the necessity of having proper occupant behavior in terms of the control of their own indoor environment. 


\section{Conclusions}

An approach to assess the effectiveness of the current passive heating and cooling methods is developed in terms of the indoor temperature increase and decrease, respectively. Based upon the indoor air temperature, and with thermal simulations that calculate the indoor temperature increase/decrease, it is found that, if the methods do not have any driving by the users, the energy consumption could be almost the same as the consumption of a regular dwelling that uses a heat pump to heat and cool the space.

After the proposed simulation modelling, which is located in Mexico City, achieves similar performances of indoor temperature decrease/increase compared with studies of passive methods under similar climate conditions, the results are considered as validated enough to analyze the different driving conditions of the passive methods.

Thus, if some operation feature, defined as mobility, maintenance, assembly, and consumables, is applied to the passive methods, the effectiveness of the passive methods is highly improved in the semi-operable and operable methods, whereas, in those which are defined as not-operable methods (phase change material, thermal insulation, and thermal capacity), the effectiveness remains almost the same. Furthermore, the improvement of the effectiveness is reflected by indoor temperatures that are closer to the temperature of comfort previously set; hence, indoor thermal comfort is achieved.

By applying an integrated driving to the passive methods, the energy saving is significant from not using a heating-cooling heat pump designed to achieved thermal comfort; it was calculated in this document to use at least 10 times less energy than is used by an air-conditioned single dwelling. Hence, it is concluded that a driving by the users is essential to achieve both thermal comfort and energy saving, once the method is installed, and not to assume correct performance without any handling on the part of the user after installation.

Funding: This research received no external funding.

Conflicts of Interest: The authors declare no conflicts of interest.

\section{Nomenclature}

$\begin{array}{ll}\varphi & \text { effectiveness of the passive methods }(0 . .1) \\ T_{\text {Passive }} & \text { indoor temperature achieved by the passive } \\ T_{\text {Comfort }} & \text { methods }\left({ }^{\circ} \mathrm{C}\right) \\ T_{l-u} & \text { indoor temperature of comfort }\left({ }^{\circ} \mathrm{C}\right) \\ C O P & \text { lower and upper range of thermal comfort }\left({ }^{\circ} \mathrm{C}\right) \\ E C & \text { coefficient of performance }(\text { dimensionless }) \\ \text { mass } & \text { mass of the indoor air }(\mathrm{kg}) \\ C p & \text { specific heat of air }\left(\mathrm{kJ} / \mathrm{kg} \cdot{ }^{\circ} \mathrm{C}\right)\end{array}$

\section{References}

1. Durand-Lasserve, O.; Pierru, A.; Smeers, Y. Uncertain long-run emission targets, $\mathrm{CO}_{2}$ price and global energy transition: A general equilibrium approach. Energy Policy 2010, 38, 5108-5122. [CrossRef]

2. Bridge, G.; Bouzarovski, S.; Bradshaw, M.; Eyre, N. Geographies of energy transition: Space, place, and the low-carbon economy. Energy Policy 2013, 53, 331-340. [CrossRef]

3. IPCC Working Group III. Special Report of Emission Scenarios. 2000. Available online: http://www.ipcc.ch/ publications_and_data/ar4/wg3/en/contents.html (accessed on 15 June 2019).

4. United Nations. Framework Convention on Climate Change. 2017. Available online: http://unfccc.int/2860. php (accessed on 15 June 2019).

5. Dogramaci, P.A.; Riffat, S.; Gan, G.; Aydin, D. Experimental study of the potential of eucalyptus fibres for evaporative cooling. Renew. Energy 2019, 131, 250-260. [CrossRef] 
6. Buonomano, A.; Forzano, C.; Kalogirou, S.A.; Palombo, A. Building-façade integrated solar thermal collectors: Energy-economic performance and indoor comfort simulation model of a water based prototype for heating, cooling, and DHW production. Renew. Energy 2019, 137, 20-36. [CrossRef]

7. Chen, W.; Zhang, S.; Zhang, Y. Analysis on the cooling and soaking-up performance of wet porous wall for building. Renew. Energy 2018, 115, 1249-1259. [CrossRef]

8. Fadaei, N.; Kasaeian, A.; Akbarzadeh, A.; Hashemabadi, S.H. Experimental investigation of solar chimney with phase change material (PCM). Renew. Energy 2018, 123, 26-35. [CrossRef]

9. Kosir, M.; Iglic, N.; Kunic, R. Optimisation of heating, cooling and lighting energy performance of modular buildings in respect to location's climatic specifics. Renew. Energy 2018, 129, 527-539. [CrossRef]

10. Montazeri, H.; Montazeri, F. CFD simulation of cross-ventilation in buildings using rooftop windcatchers: Impact of outlet openings. Renew. Energy 2018, 118, 502-520. [CrossRef]

11. Mukhtar, A.; Ng, K.C.; Yusoff, M.Z. Passive thermal performance prediction and multi-objective optimization of naturally-ventilated underground shelter in Malaysia. Renew. Energy 2018, 123, 342-352. [CrossRef]

12. Rosso, F.; Golasi, I.; Castaldo, V.L.; Piselli, C.; Pisello, A.L.; Salata, F.; Ferrero, M.; Cotana, F.; Vollaro, A.L. On the impact of innovative materials on outdoor thermal comfort of pedestrians in historical urban canyons. Renew. Energy 2018, 118, 825-839. [CrossRef]

13. Yu, J.; Ye, H.; Xu, X.; Huang, J.; Liu, Y.; Wang, J. Experimental study on the thermal performance of a hollow block ventilation wall. Renew. Energy 2018, 122, 619-631. [CrossRef]

14. Zhao, J.; Bilbao, J.I.; Spooner, E.D.; Sproul, A.B. Experimental study of a solar pool heating system under lower flow and low pump speed conditions. Renew. Energy 2018, 119, 320-335. [CrossRef]

15. Vassiliades, C.; Michael, A.; Savvides, A.; Kalogirou, S. Improvement of passive behaviour of existing buildings through the integration of active solar energy systems. Energy 2018, 163, 1178-1192. [CrossRef]

16. Bakos, G.C. Electrical energy saving in a passive-solar-heated residence using a direct gain attached sunspace. Energy Build. 2013, 35, 147-151. [CrossRef]

17. Barea, G.; Ganem, C.; Esteves, A. The multi-azimuthal window as a passive solar system: A study of heat gain for the rational use of energy. Energy Build. 2017, 144, 251-261. [CrossRef]

18. Oh, M.H.; Lee, K.H.; Yoon, J.H. Automated control strategies of inside slat-type blind considering visual comfort and building energy performance. Energy Build. 2013, 59, 728-737. [CrossRef]

19. Tzempelikos, A.; Athienitis, A.K. The impact of shading design and control on building cooling and lighting demand. Sol. Energy 2007, 81, 369-382. [CrossRef]

20. David, M.; Donn, M.; Garde, F.; Lenoir, A. Assessment of the thermal and visual efficiency of solar shades. Build. Environ. 2011, 46, 1489-1496. [CrossRef]

21. Babota, F.; Moga, L. Computation and analysis of corrected thermal insulation in a common dwelling building in Romania, in various thermal insulation variants-The slab over the soil. Procedia Manuf. 2018, 22, 352-357. [CrossRef]

22. Glew, D.; Brooke-Peat, M.; Gorse, C. Modelling insulated coving's potential to reducing thermal bridging and moisture risk in solid wall dwellings retrofitted with external wall insulation. J. Build. Eng. 2017, 11, 216-223. [CrossRef]

23. Hedayatizadeh, M.; Sarhaddi, F.; Safavinejad, A.; Ranjbar, F.; Chaji, H. Exergy loss-based efficiency optimization of a double-pass/glazed v-corrugated plate solar air heater. Energy 2016, 94, 799-810. [CrossRef]

24. Flores Larsen, S.; Rengifo, L.; Filippín, C. Double skin glazed façades in sunny Mediterranean climates. Energy Build. 2015, 102, 18-31. [CrossRef]

25. Pomianowski, M.S.; Heiselberg, P.K.; Zhang, Y. Review of thermal energy storage based on PCM application in buildings. Energy Build. 2013, 67, 56-69. [CrossRef]

26. Song, G.; Ma, S.; Tang, G.; Yin, Z.; Wang, X. Preparation and characterization of flame retardant for-stable phase change materials composed by EPDM, paraffin and nano magnesium hydroxide. Energy 2010, 35, 2179-2183. [CrossRef]

27. Zhou, D.; Zhao, C.Y.; Tian, Y. Review of thermal energy storage with phase change materials (PCM) in building applications. Appl. Energy 2012, 92, 593-605. [CrossRef]

28. Waqas, A.; Ud Din, Z. Phase change material (PCM) storage for free cooling of buildings-A review. Renew. Sustain. Energy Rev. 2013, 18, 607-625. [CrossRef] 
29. Gianolo, G.; Rosso, I.; Mercante, L.; Pedrazzo, F.; Simonato, G.; Ceriani, F. GreenShelter for telecom applications: A new generation of shelters for telecom applications integrating fuel cell electric backup and new cooling approach. In Proceedings of the 2008 IEEE 30th International Telecommunications Energy Conference, San Diego, CA, USA, 14-18 September 2008.

30. Givoni, B. Cooled soil as cooling source for buildings. Sol. Energy 2007, 81, 316-328. [CrossRef]

31. Hasan, A.A.; Eusuf, M.A. Study the heat sink potential of building ground floor slab integrated with ELT. Appl. Mech. Mater. 2013, 268, 967-973. [CrossRef]

32. Abdou, O.A.; Hamid, A.A. Thermal energy performance of load-bearing concrete masonry in residential buildings in hot, dry climates. Energy Sources 1993, 15, 159-170. [CrossRef]

33. Yarbrough, D.W.; Anderson, R.W. Use or radiation control coatings to reduce building air-conditioning loads. Energy Sources 1993, 15, 59-66. [CrossRef]

34. Berdahl, P.; Bretz, S.E. Preliminary survey of the solar reflectance of cool roofing materials. Energy Build. 1997, 25, 149-158. [CrossRef]

35. Suehrcke, H.; Peterson, E.L.; Selby, N. Effect of roof solar reflectance on the building heat gain in a hot climate. Energy Build. 2008, 40, 2224-2235. [CrossRef]

36. Younes, C.; Caesar, A.S.; Girma, B. Air infiltration through building envelopes: A review. J. Build. Phys. 2011, 35, 267-302. [CrossRef]

37. Qiu, G.Q.; Riffat, S.B. Novel design and modelling of an evaporative cooling system for buildings. Int. J. Energy Resour. 2006, 30, 985-999. [CrossRef]

38. Belarbi, R.; Ghiaus, C.; Allard, F. Modeling of water spray evaporation: Application to passive cooling of buildings. Sol. Energy 2006, 80, 1540-1552. [CrossRef]

39. He, J.; Hoyano, A. Experimental study of cooling effects of a passive evaporative cooling wall constructed of porous ceramics with high water soaking-up ability. Build. Environ. 2010, 45, 461-472. [CrossRef]

40. He, J. A design supporting simulation system for predicting and evaluating the cool microclimate creating effect of passive evaporative cooling walls. Build. Environ. 2011, 46, 584-596. [CrossRef]

41. Le Dréau, J.; Heiselberg, P.; Jensen, R.L. Experimental investigation of convective heat transfer during night cooling with different ventilation systems and surface emissivities. Energy Build. 2013, 61, 308-317. [CrossRef]

42. Artmann, N.; Jensen, R.L.; Manz, H.; Heiselberg, P. Experimental investigation of heat transfer during night-time ventilation. Energy Build. 2010, 42, 366-374. [CrossRef]

43. Artmann, N.; Manz, H.; Heiselberg, P. Parameter study on performance of building cooling by night-time ventilation. Renew. Energy 2008, 33, 2589-2598. [CrossRef]

44. Henning, H.M. Solar assisted air conditioning of buildings-An overview. Appl. Therm. Eng. 2007, 27, 1734-1749. [CrossRef]

45. Zeyghami, M.; Goswami, D.Y.; Stefanakos, E. A review of solar thermo-mechanical refrigeration and cooling methods. Renew. Sustain. Energy Rev. 2015, 51, 1428-1445. [CrossRef]

46. Gebreslassie, B.H.; Guillen-Gosalbez, G.; Jimenez, L.; Boer, D. Solar assisted solar cooling cycles for reduction of global warming: A multi-objective optimization approach. Sol. Energy 2012, 86, 2083-2094. [CrossRef]

47. Albers, J. New absorption chiller and control strategy for the solar assisted cooling system at the German environment agency. Int. J. Refrig. 2014, 39, 48-56. [CrossRef]

48. Shirazi, A.; Pintaldi, S.; White, S.D.; Morrison, G.L.; Rosengarten, G.; Taylor, R.A. Solar assisted absorption air-conditioning systems in buildings: Control strategies and operational modes. Appl. Therm. Eng. 2016, 92, 246-260. [CrossRef]

49. Agathokleous, R.A.; Kalogirou, S.A. Double skin facades (DSF) and building integrated photovoltaics (BIPV): A review of configurations and heat transfer characteristics. Renew. Energy 2016, 89, 743-756. [CrossRef]

50. Pomponi, F.; Piroozfar, P.A.E.; Southall, R.; Ashton, P.; Farr, E.R.P. Energy performance of Double-skin facades in temperate climates: A systematic review and meta-analysis. Renew. Sustain. Energy Rev. 2016, 54, 1525-1536. [CrossRef]

51. GhaffarianHoseini, A.; Berardi, U.; GhaffarianHoseini, A.; Makaremi, N. Intelligent facades in low energy buildings. Br. J. Environ. Clim. Chang. 2012, 2, 437-464. [CrossRef]

52. Kensek, K.; Hansanuwat, R. Environment control systems for sustainable design: A methodology for testing, simulating and comparing kinetic facade systems. J. Creat. Sustain. Archit. Built Environ. 2011, 1, $27-46$. 
53. Oropeza-Perez, I.; Østergaard, P.A. Active and passive cooling for dwellings: A review. Renew. Sustain. Energy Rev. 2018, 82, 531-544. [CrossRef]

54. Manzano-Agugliaro, F.; Montoya, F.G.; Sabio-Ortega, A.; Garcia-Cruz, A. Review of bioclimatic architecture strategies for achieving thermal comfort. Renew. Sustain. Energy Rev. 2015, 49, 735-755. [CrossRef]

55. Goyal, S.; Ingley, H.A.; Barooah, P. Occupancy-based zone-climate control for energy-efficient buildings: Complexity vs performance. Appl. Energy 2013, 106, 209-221. [CrossRef]

56. Martani, C.; Lee, D.; Robinson, P.; Britter, R.; Ratti, C. ENERNET: Studying the dynamic relationship between building occupancy and energy consumption. Energy Build. 2012, 47, 584-591. [CrossRef]

57. Jia, M.; Snirivasan, R.S.; Raheem, A.A. From occupancy to occupant behavior: An analytical survey of data acquisition technologies, modeling methodologies and simulation coupling mechanisms for building energy efficiency. Renew. Sustain. Energy Rev. 2017, 68, 525-540. [CrossRef]

58. Blumenfeld, A.; Thumm, W.T. Passive building systems vs active building systems and the return of investment. In Building Innovation 2014; National Institute of Building Sciences: Washington, DC, USA, 2014.

59. Tanner, R.A.; Henze, G.P. Quantifying the impact of occupant behavior in mixed mode buildings. In AEI 2013: Building Solutions for Architectural Engineering; American Society of Civil Engineers: Reston, VA, USA, 2013.

60. Daly, A. Operable windows and HVAC systems. HPAC Heat. Pip. Air Cond. Eng. 2002, 74, $22-30$.

61. Harvey, L.D.D. Energy savings by treating buildings as systems. AIP Conf. Proc. 2008, 1044, 67-87.

62. Wei, S.; Hassan, T.M.; Firth, S.K.; Fouchal, F. Impact of occupant behaviour on the energy-saving potential of retrofit measures for a public building in the UK. Intell. Build. Int. 2017, 9, 97-106. [CrossRef]

63. Foruzanmehr, A.; Vellinga, M. Vernacular architecture: Questions of comfort and practicability. Build. Res. Inf. 2011, 39, 274-285. [CrossRef]

64. Schulze, T.; Gürlich, D.; Eicker, U. Performance assessment of controlled natural ventilation for air quality control and passive cooling in existing and new office type buildings. Energy Build. 2018, 172, 265-278. [CrossRef]

65. Zhang, R.; Nie, Y.; Lam, K.P.; Biegler, L.T. Dynamic optimization based integrated operation strategy design for passive cooling ventilation and active building air conditioning. Energy Build. 2014, 85, 126-135. [CrossRef]

66. Blanco, I.; Schettini, E.; Scarascia Mugnozza, G.; Campiotti, C.A.; Giagnacovo, G.; Vox, G. Vegetation as a passive system for enhancing building climate control. Acta Hortic. 2017, 1170, 555-561. [CrossRef]

67. Kim, S.; Chang, J.D.; Yun, G.Y.; Kim, S. Polymer composites for passive control system of buildings. Int. J. Polym. Sci. 2017, 97, 662-674. [CrossRef]

68. Yan, F.; Zhu, S. Research on energy consumption control of campus public buildings based on passive design. Int. J. Earth Sci. Eng. 2016, 9, 1845-1851.

69. Rijal, H.B.; Humphreys, M.A.; Nicol, J.F. How do the occupants control the temperature in mixed-mode buildings? Predicting the use of passive and active controls. In Proceedings of the Air Conditioning and the Low Carbon Cooling Challenge, Windsor, UK, 27 July 2008.

70. Foster, M.; Oreszczyn, T. Occupant control of passive systems: The use of Venetian blinds. Build. Environ. 2001, 36, 149-155. [CrossRef]

71. Oropeza-Perez, I.; Petzold-Rodriguez, A.H.; Bonilla-Lopez, C. Adaptive thermal comfort in the main Mexican climate conditions with and without passive cooling. Energy Build. 2017, 145, 251-258. [CrossRef]

72. U. S. Department of Energy. Energy Plus Software. Available online: http:/apps1.eere.energy.gov/buildings/ energyplus (accesed on 12 July 2018).

73. Oropeza-Perez, I.; Ostergaard, P.A.; Remmen, A. Model of natural ventilation by using a coupled thermal-airflow simulation program. Energy Build. 2012, 49, 388-393. [CrossRef]

74. Oropeza-Perez, I.; Ostergaard, P.A. Energy saving potential of utilizing natural ventilation under warm conditions-A case study of Mexico. Appl. Energy 2014, 130, 20-32. [CrossRef]

75. Google Maps. 2019. Available online: https://snazzymaps.com (accessed on 12 October 2019).

76. Zhu, J.; Chen, B. Experimental study on thermal response of passive solar house with color changed. Renew. Energy 2015, 73, 55-61. [CrossRef]

77. Alders, E.E. Adaptive heating, ventilation and solar shading for dwellings. Archit. Sci. Rev. 2017, 60, 150-166. [CrossRef]

78. Garcia Chavez, J.R.; Fernandez Melchor, F. Application of combined passive cooling and passive heating techniques to achieve thermal comfort in a hot dry climate. Energy Procedia 2013, 57, 1669-1676. [CrossRef] 
79. Nyers, J.M.; Nyers, A.J. COP of heating-cooling system with heat pump. In Proceedings of the EXPRES 2011-3rd IEEE International Symposium on Exploitation of Renewable Energy Sources, Subotica, Serbia, 11-12 March 2011; pp. 17-21.

80. Oropeza-Perez, I. Comparative economic assessment of the energy performance of air-conditioning within the Mexican residential sector. Energy Rep. 2016, 2, 147-154. [CrossRef]

81. Department for Communities and Local Government. Technical Housing Standards—Nationally Described Space Standard; Department for Communities and Local Government: London, UK, 2015; ISBN 978-1-4098-4567-6.

82. Etheridge, D. Natural Ventilation of Buildings: Theory, Measurement and Design, 1st ed.; John Wiley \& Sons Ltd.: Hoboken, NJ, USA, 2012.

83. Oropeza-Perez, I. Development of a cooling-load calculator for the Mexican conditions of climate, construction and occupancy. Procedia Eng. 2017, 205, 1115-1122. [CrossRef]

(C) 2019 by the author. Licensee MDPI, Basel, Switzerland. This article is an open access article distributed under the terms and conditions of the Creative Commons Attribution (CC BY) license (http://creativecommons.org/licenses/by/4.0/). 